\title{
JEFFREY PINE SEED DISPERSAL IN THE SIERRA SAN PEDRO MÁRTIR, BAJA CALIFORNIA, MEXICO
}

\author{
Stephen B. Vander Wall ${ }^{1}$, Mark S. Enders², Sarah Barga ${ }^{2}$, Christopher Moorel, \\ Amy Seaman ${ }^{1}$, and Ramón Perea ${ }^{3}$
}

\begin{abstract}
The Sierra San Pedro Mártir (SSPM) in northern Baja California, Mexico, is a remote mountain at the southern edge of the California Floristic Province, a vegetation type that includes the Sierra Nevada of California and western Nevada. Unlike most forests in the southwestern United States, the forests of the SSPM have never been logged and have experienced only light grazing in recent years, and wildfires have not been suppressed until recent decades. The SSPM represents one of the best examples of an intact presettlement forest in the California Floristic Province. We investigated the mode of seed dispersal of Jeffrey pine (Pinus jeffreyi) in the SSPM, and compared it to that from the eastern slope of the Sierra Nevada, to determine how this process might differ between nearly pristine and heavily altered forests. We found that seed dispersal appears to occur by the same means in both forests (i.e., scatter hoarding of seeds by rodents), but that seedling establishment is much less successful in the SSPM. We considered several hypotheses for why this difference might exist, including the size of seed crops, fire regimes, climate change, grazing by domestic ungulates, and lack of facilitation by shrubs (i.e., nurse plants), but none of these explanations appears adequate to account for the difference. Instead, we suggest that the slow rate of seedling establishment at the SSPM is due to a greater consumption of seeds cached by California chipmunks (Tamias obscurus), who experience a relatively long period of euthermic winter activity in the warm climate of the SSPM. This greater consumption leaves few seeds to germinate. Future studies should test the relative importance of these alternative causes for low seedling recruitment at the SSPM.
\end{abstract}

Resumen.-La Sierra de San Pedro Mártir (SSPM) en Baja California Norte, México es un conjunto remoto de montañas en el extremo sur de la Provincia Florística de California, un tipo de vegetación que incluye la Sierra Nevada de California y el oeste de Nevada. A diferencia de la mayoría de los bosques en el suroeste de los Estados Unidos, los bosques de la SSPM no se han talado, solo han experimentado pastoreo ligero en años recientes y no se ha acometido la extinción de los incendios hasta décadas recientes. La SSPM representa uno de los mejores ejemplos de un bosque intacto pre-asentamiento en la Provincia Florística de California. Investigamos la forma de dispersión de la semilla del pino Jeffrey (Pinus jeffreyi) en la SSPM y lo comparamos con la de la zona este de la Sierra Nevada, para determinar de qué manera este proceso puede diferir entre bosques casi prístinos y bosques sumamente alterados. Encontramos que la dispersión de las semillas parece producirse mediante los mismos medios en ambos bosques (i.e., acumulación dispersa de semillas por parte de roedores) pero que el establecimiento de las plántulas es mucho menos exitoso en la SSPM. Consideramos varias hipótesis de por qué podría existir esta diferencia, incluyendo el tamaño de las semillas, los regímenes de fuego, el cambio climático, el efecto de ungulados domésticos y la falta de facilitación por parte de arbustos (i.e., plantas nodrizas), pero ninguna de estas explicaciones parece ser adecuada para explicar la diferencia. En lugar de esto, sugerimos que la baja tasa de establecimiento de plántulas en la SSPM se debe a que el clima más cálido resulta en un periodo más largo de actividad eutérmica en invierno de las ardillas de California (Tamias obscurus), lo que resulta en un mayor consumo de semillas acumuladas durante el invierno, lo que implica que muy pocas de ellas puedan germinar. Estudios futuros deben examinar la importancia relativa de estas causas alternativas del escaso reclutamiento de plántulas en la SSPM.

Nearly all forests in the United States have been altered by past management decisions (e.g., Brown et al. 2004, Laughlin et al. 2004, Collins et al. 2011). Many of the forests of the Sierra Nevada, for example, were clear-cut between 1860 and 1890 (Lindstrom 2000, Taylor 2004), and many of the larger trees in replacement forests have been harvested in recent years. Starting in the 1880 s and continuing through the 1960s, cattle and sheep heavily grazed many of the second growth forests, removing much of the fine fuels (Finch et al. 1997). Starting in the 1890s, wildfire was suppressed (Parsons and DeBenedetti 1979, Agee and Skinner 2005, Stephens and Ruth 2005). Some pine forests in the east slope of the

\footnotetext{
${ }^{1}$ Department of Biology and Program in Ecology, Evolution and Conservation Biology, University of Nevada, Reno, NV 89557. E-mail: sv@unr.edu ${ }^{2}$ Great Basin Institute, 16750 Mount Rose Highway, Reno, NV 89511.
}

${ }^{3}$ Departamento de Silvopascicultura. ETSI Montes, Universidad Politécnica de Madrid, Ciudad Universitaria s/n, 28040 Madrid, Spain. 
Sierra Nevada have not burned in over 100 years (Stephens 2001, Taylor 2004, Beaty and Taylor 2008). The absence of fire in these forests has resulted in increased seedling establishment, dense stands of trees, heavy fuel loads, and increased risks of catastrophic fire (Stephens 2001). Before European settlement, the median fire-return interval in this region ranged from 3 to 15 years (Taylor 2004, Taylor and Beaty 2005, Vaillant and Stephens 2009, North et al. 2009). These fires were relatively small, were of low to moderate intensity, and served to remove most dead and downed fuels. Because of these studies, we know that the structure of extant forests differs greatly from the structure of presettlement forests. What is not so clear, however, is whether the ecological processes that operate in extant forests are the same as those that operated in presettlement forests.

On the east slope of the Sierra Nevada, Jeffrey pine (Pinus jeffreyi), a dominant tree at low to mid-elevations, is dispersed to a very large extent by seed-caching rodents and corvids (Tomback 1978, Vander Wall 1994, 2002, 2003, 2008, Vander Wall et al. 2001, Thayer and Vander Wall 2005, Gworek et al. 2007, Briggs et al. 2009). The importance of animals in the dispersal of Jeffrey pine seeds is surprising because the seeds are winged and released from cones at maturity to be scattered by the wind. However, a variety of animals gather the seeds and cache them in soil. Since these seeds appear adapted for wind dispersal, one might ask to what extent Jeffrey pine seeds were dispersed by animals in pristine forests before European settlers altered the structure of those forests. Did the pattern and process of pine seedling recruitment in presettlement forests differ from those we see today? These questions are not answerable in the United States because there are no western forests that have been unaffected by over a century of logging, grazing, or fire suppression. In contrast, the forest of the Sierra San Pedro Mártir (SSPM) in Mexico provides a unique opportunity to ask these questions. Although not truly pristine, this forest has never been logged, had not been subjected to wildfire suppression until the 1970s, and has received grazing of varying but generally low intensity since the late 1800s (Minnich et al. 2000, Stephens et al. 2003).

Further, the composition of the forest in the SSPM (Minnich et al. 2000, Stephens et al. 2003, Stephens 2004, Stephens and Gill 2005) is nearly identical to the composition in the east slope of the Sierra Nevada. The SSPM is $600-1200 \mathrm{~km}$ south of the Sierra Nevada and separated by hundreds of kilometers of desert habitat, but these forests share nearly all tree species, including Jeffrey pine, sugar pine (Pinus lambertiana), lodgepole pine (Pinus contorta), white fir (Abies concolor), incense cedar (Calocedrus decurrens), and aspen (Populus tremuloides). The understory vegetation at both sites includes greenleaf manzanita (Arctostaphylos patula), snowberry (Symphoricarpos sp.), buckbrush (Ceanothus sp.), lupine (Lupinus sp.), buckwheat (Eriogonum sp.), bracken fern (Pteridium aquilium), and snow plant (Sarcodes sanguinea). Soils at both sites are derived from decomposed granite. Stephens et al. (2003) recorded median point fire-return intervals of 22.5 years (range 12.4-54.7) and median composite fire-return intervals of 5-13 years (range 1-43) in the SSPM. They concluded that fire frequencies there were similar to those in Jeffrey pine forests in the eastern Sierra Nevada before European settlement. Consequently, the SSPM represents the best extant example of the likely state of the eastern Sierra Nevada before it was logged in the 1870s and experienced more than a century of fire suppression.

Many of the animal species in the Sierra Nevada are shared with the SSPM or are represented there by ecologically similar species. The shared potential seed dispersers of Jeffrey pine include deer mice (Peromyscus maniculatus), piñon mice (Peromyscus truei), California ground squirrel (Spermophilus beecheyi), and Steller's Jay (Cyanocitta stelleri) (Vander Wall et al. 2001, Thayer and Vander Wall 2005). Both forests have chipmunks: California chipmunk (Tamias obscurus) in the SSPM instead of yellow-pine chipmunk (Tamias amoenus), long-eared chipmunk (Tamias quadrimaculatus), and lodgepole chipmunk (Tamias speciosus) at our study site on the east slope of the Sierra Nevada.

The objective of this study was to assess the importance of animals in the dispersal and establishment of Jeffrey pines in the SSPM. Ultimately, we sought to determine how plantanimal interactions in nearly pristine forests differ from those we have studied in highly altered forests of the Sierra Nevada. This information will help us to better understand forest dynamics of the SSPM and thereby better manage forests in the western United States. 


\section{Methods}

\section{Study Area}

The Sierra San Pedro Mártir is the southern terminus of the Peninsular Range in northern Baja California, Mexico. The SSPM lies at the southern edge of the California floristic province, a vegetation type that includes much of the Sierra Nevada of California and western Nevada. Our study site in the SSPM lies $\sim 120 \mathrm{~km}$ southeast of Ensenada $\left(31^{\circ} 37^{\prime} \mathrm{N}, 115^{\circ} 39^{\prime} \mathrm{W}\right)$ on the southwestern edge of Vallecitos Meadow and at an elevation of about $2500 \mathrm{~m}$ (Minnich et al. 2000). The site usually receives between 550 and $700 \mathrm{~mm}$ of precipitation annually. Most precipitation falls in winter in the form of snow; except for infrequent thunderstorms, summers are warm and dry. The study occurred in a mixed-conifer zone dominated by Jeffrey pine.

\section{Rodent Trapping}

We trapped small mammals using collapsible Sherman live traps on a 40-trap grid $(4 \times 10$ grid) with 12-m spacing between traps. Traps were baited with sunflower seeds. We checked traps in the morning for nocturnal rodents and in the evening for diurnal rodents. We eartagged all subjects for individual recognition and recorded species, age, mass, gender, and reproductive condition. We released animals at the site of capture. We trapped for 3 days from 19 to 21 June 2006 and 3 days from 15 to 17 July 2009. Population sizes were estimated as the total number of individuals captured for each species.

\section{Seed Removal}

Jeffrey pine produces winged seeds that are initially scattered by the wind and subsequently gathered by animals, some of which cache the seeds in soil (e.g., Vander Wall 2008). We established 3 seed-removal transects to measure the rate at which animals remove simulated winddispersed seeds from the ground. To prevent the wind from moving seeds, we tethered them to twigs using a short $(\sim 40 \mathrm{~cm})$ brown thread. We spaced individual seeds $\sim 5 \mathrm{~m}$ apart along 3 wandering transects through the study site. Each transect had 50 seed stations. We used seeds from Nevada but irradiated them to prevent genetic contamination of local populations if the seeds were to survive and germinate. We checked transects each morning for 3 days in 2006 and for 4 days in 2009 to record removed and eaten seeds. At the end of the study, we opened all remaining seeds to ensure that all seeds were filled and edible. We used survival analysis (Program R, Version 2.12.2) with interval censoring and a Weibull distribution to determine the mean number of days until removal of a cache. This allowed us to compare seed-removal rates among transects and between years.

\section{Seed Caching}

We determined the fates of removed Jeffrey pine seeds by dusting seeds with fluorescent power and searching for seeds at night using a black light (Longland and Clements 1995). In the evening, we placed 200 irradiated Jeffrey pine seeds on paper plates mixed with $\sim 10 \mathrm{~g}$ of fluorescent dye. We established 9 stations in 2006 and 7 stations in 2009 at the base of stumps, boulders, logs, or tree trunks. The following day, we inspected each station and noted those that had seeds removed. Three fates were expected: eaten, taken into a burrow and larder hoarded, or scatter hoarded in the ground surface. Scatter-hoarded seeds could germinate if not recovered by spring. The next night we followed the tracks of animals that had removed seeds, and we searched for eaten and cached seeds. We excavated cached seeds and determined cache sizes, cache depth, cache microsite, and minimum dispersal distances. All data are means \pm 1 SD.

\section{Seedling Plots}

We estimated natural seedling recruitment to gauge past reproductive success in 2009 . We established 10 random plots $(10 \times 10 \mathrm{~m})$ to census young Jeffrey pine $(<3 \mathrm{~m}$ tall $)$ and other conifer seedlings and saplings. We recorded seedlings growing in clumps and measured the height of each seedling or sapling.

\section{RESUlTS}

\section{Rodent Trapping}

The species composition was the same in both years of study, but we caught many more animals in 2006 than in 2009. In 2006, we caught 18 California chipmunks, 5 deer mice, 4 California ground squirrels, and 1 piñon mouse, for a total of 28 individuals. In 2009, the numbers were 11 chipmunks, 1 deer mouse, 3 ground squirrels, and 1 piñon mouse, for a total of 16 individuals. 


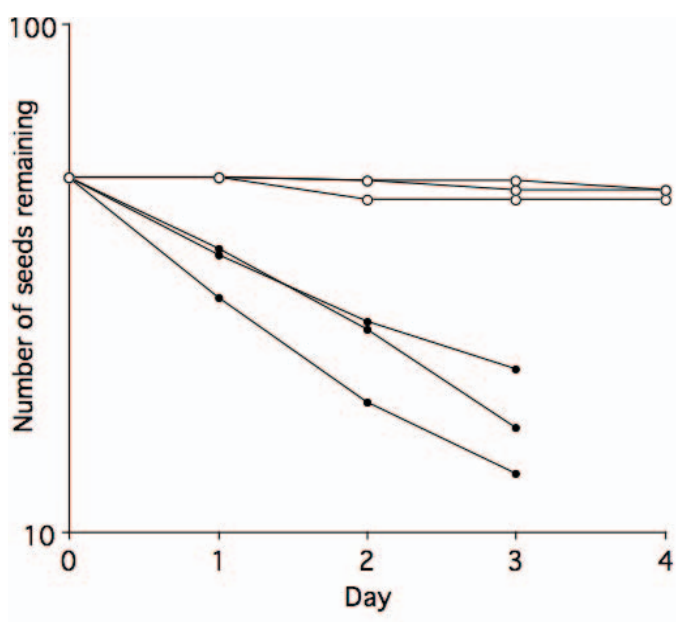

Fig. 1. Removal of Jeffrey pine (Pinus jeffreyi) seeds by animals from along 3 transects in June 2006 (closed circles) and July 2009 (open circles) in the Sierra San Pedro Mártir. Number of seeds remaining is plotted on a log scale; all transects started with 50 seeds.

\section{Seed Removal}

Animals removed Jeffrey pine seeds much faster in 2006 than in $2009(Z=7.65, P<$ 0.0001 ) (Fig. 1). In 2006, rates of removal along the 3 transects were $25.1 \%, 31.6 \%$, and $36.2 \%$ per day, for an overall rate of $31.0 \%$ (SD = $5.6)$ per day. The mean number of days to remove seeds was 2.7 days in 2006. In 2009, rates were $1.5 \%, 2.6 \%$, and $1.5 \%$ per day, with an overall rate of $1.9 \%(\mathrm{SD}=0.6)$ per day and a mean of 44 days to remove seeds. There was no significant difference between transects within years. In $2006,18 \%$ of the seeds that animals removed were eaten at the station, and in 2009, $40 \%$ of the found seeds had been eaten. Animals removed all other seeds intact.

\section{Seed Caching}

In 2006, tracks indicated that seeds at 6 fluorescent dye stations were taken by California chipmunks, seeds at 2 stations were taken by California ground squirrels, and seeds at one station were never harvested by animals. Tracks of other rodents or Steller's jays were not present. The tracks (and other observations) suggested that chipmunks took multiple loads of seeds short distances and stored the seeds in the ground. Unfortunately, it was very difficult to locate cache sites on the pine needle substrate where most trials originated. We found only 3 caches, each containing one seed buried 1-2 cm deep in soil. However, based on behavior of chipmunks and deer mice elsewhere (and our results from 2009), we suspect that many of the $\sim 1200$ removed seeds were scatter hoarded in a similar fashion (e.g., Vander Wall 1995, Vander Wall et al. 2001). Seeds taken by California ground squirrels were probably taken to chambers deep below ground.

In 2009, we placed seed trays in similar situations but on mineral soil, which proved a better tracking substrate. At 3 seed trays, rodents removed most or all of the seeds without eating any at the seed station and without making any surface caches that we could find. Most seeds appeared to have been taken into burrows beneath large boulders. At 2 other sites, we found 3 and 13 cache sites, respectively, but the cached seeds had already been removed. These sites consisted of shallow pits with traces of fluorescent dye, suggesting that the rodent had made temporary caches that existed for only a few hours. Other seeds with fluorescent dye were found eaten nearby. At the sixth site, we found 4 caches (plus 4 empty cache sites) and many eaten seeds with fluorescent dye. All extant caches contained only one seed and were $429 \pm 250 \mathrm{~cm}$ from the source. At the final site, we found 29 intact caches containing 76 seeds. Caches contained $2.6 \pm 1.4$ seeds (range 1-6) that were only partially buried; the uppermost seeds were visible through the plant litter or soil. Based on small size and shallow burial, these caches appeared to be the work of a deer mouse (Vander Wall et al. 2001). Cache sites were located $942 \pm$ $595 \mathrm{~cm}$ from the source (range 186-2249 cm). Most of these caches were located in dense vegetation near large boulders. Similar to several of the other sites, most of these caches were short-lived; 12 caches disappeared the next night and an additional 10 caches disappeared the following night. Two days after the study, only 7 of 29 caches remained.

\section{Seedling Plots}

We found only 10 Jeffrey pine seedlings and saplings on the 10 census plots $(1.0 \pm 1.2$ saplings per plot; range $0-4)$. None of the pines were recent seedlings; the shortest sapling was $21 \mathrm{~cm}$ tall. There were 3 saplings between 1 and $2 \mathrm{~m}$ tall and 1 sapling between 2 and $3 \mathrm{~m}$ tall on the plots. We also counted 1 lodgepole pine, 1 sugar pine, and 3 white fir saplings between 39 and $100 \mathrm{~cm}$ tall. The cover of the 
plots consisted of open mineral soil, patches of pine needle litter with rotting cones, granite boulders, and scattered snowberry bushes.

\section{Discussion}

We trapped more rodents in 2006 than in 2009. This apparent population decline may have been related to the lack of significant production of Jeffrey pine and sugar pine seeds in the intervening years (based on the absence of fresh cones), as these seeds are likely important autumn and winter foods of all rodents in the SSPM. However, several other causes may have contributed to the decline in population size. The number of rodents that we trapped at the SSPM was comparable to the number trapped at our study site in the Carson Range in western Nevada, USA. For example, Vander Wall $(2002,2003)$ and Thayer and Vander Wall (2005) reported average population sizes of 12-43 chipmunks in 5 days of trapping in western Nevada, whereas we caught 11-18 chipmunks over 3 days of trapping at the SSPM on trapping grids of the same size. The numbers for Peromyscus spp. (hereafter, deer mice) were 1.6-9.5 in Nevada versus 2-6 in the SSPM. Thus, the abundance of scatter-hoarding rodents that could serve as consumers and as potential agents of Jeffrey pine seed dispersal in the 2 forests was broadly similar.

Rates of seed removal from the ground were also similar, at least in 2006. For example, Vander Wall (2008) reported average rates of Jeffrey pine seed removal of $34 \% \pm 17 \%$ per day in open Jeffrey pine forests $(n=24$ transects) and $7.7 \% \pm 9.6 \%$ per day in closed-canopy Jeffrey pine forests $(n=11$ transects; see Vander Wall 1994 and Gworek et al. 2007 for similar data on Jeffrey pine seed removal) compared to a mean of $31 \% \pm 6 \%$ per day in this study in 2006. The rates of Jeffrey pine seed removal at SSPM in 2009 were much slower $(\bar{x}=1.9 \% \pm 0.6 \%$ per day), but 5 of the 11 seedremoval transects in closed-canopy Jeffrey pine forests in Nevada were comparable, ranging from $1.2 \%$ to $3.8 \%$ per day. These slow rates of seed removal were recorded in open forests with sparse cover for rodents during years of low seed production, conditions similar to those in the SSPM in 2009. As in Nevada (Vander Wall 2008), most of the seeds removed from transects at the SSPM were taken intact (i.e., not eaten), allowing the possibility that some seeds could have been stored for future use. Further, even though seed removal rates may be slow, rodents and jays eventually harvest nearly all seeds that fall from cones, making these animals important seed predators and, when they cache seeds, important causes of seedling establishment (e.g., Vander Wall 2008, Briggs et al. 2009).

We found far fewer cached Jeffrey pine seeds in our fluorescent seed study than we typically find scatter hoarded at our Nevada study site. However, this difference between sites is probably due to the different methodologies employed. In Nevada, we use radioactive scandium-46 to track seeds harvested by rodents. This is a very effective method, and we usually find 25-50 caches when we offer 150-200 seeds to foraging rodents (e.g., Vander Wall 1995, 2000, Vander Wall et al. 2001). Only one of 16 trials had that many caches in the SSPM, likely because the fluorescent powder method is much less efficient, and, in our experience, the success of the method depends on the caching substrate. We had more difficulty finding seed caches in litter substrates than in soil substrates, and we had more difficulty finding deeply buried seeds than shallowly buried seeds. Despite these methodological difficulties, we conclude that the propensity of chipmunks and Peromyscus sp. in the SSPM to scatter hoard seeds is similar to that of their conspecifics and congeners in the Sierra Nevada. Many of the caches in the SSPM were short lived, but this probably reflects the timing of the studies (June and July). Studies were conducted well before the time of Jeffrey pine seed availability (late August to September) and at a time when little other food is available.

Seedling and sapling densities on the $10 \times$ $10-\mathrm{m}$ plots in the SSPM were dramatically lower than those recorded in Nevada. In Nevada, seedling plots of the same size at midelevation sites typically have from 50 to 300 seedlings of varying sizes (Gworek et al. 2007, Briggs et al. 2009). Virtually all of these seedlings were attributed to animal caching (see rationale in Briggs et al. 2009), and from onethird to one-half of the seedlings grow in clumps. In contrast, plots at the SSPM had no seedlings and only about one Jeffrey pine sapling per plot. We observed very low sapling densities off the sample plots as well, and this appears to be typical of the region. Stephens and Gill (2005) reported 101.2 $(\mathrm{SE}=13.5)$ Jeffrey pine seedling and saplings $(<2.5 \mathrm{~cm}$ $\mathrm{dbh})$ per hectare in the SSPM at a site $\sim 5 \mathrm{~km}$ 
from our study site. This is equivalent to $\sim 1$ seedling or sapling per $100 \mathrm{~m}^{2}$. They also found that seedlings and saplings were distributed patchily (range $0-410$ seedlings and saplings per ha). Similar values have been reported by Minnich et al. (2000) and Stephens and Fry (2005).

We can offer several possible explanations for this relatively low rate of Jeffrey pine regeneration in the SSPM. The lack of young seedlings on our study plots is at least partially because there had not been a sizable Jeffrey pine seed crop in the vicinity of our sample plots since before autumn 2004 (based on the lack of recent cones on the ground in 2006 and 2009), although abundant old, decaying cones attest to numerous large cone crops in the nottoo-distant past. At our study site in the eastern Sierra Nevada, Jeffrey pines produce moderate to large cone crops every $2-3$ years (range 10 \pm 28 to $127 \pm 100$ cones per mature tree over 5 years, $n=27$ trees; Vander Wall 2008). Jeffrey pine seedlings and small saplings grow very slowly in these arid ecosystems (Vander Wall unpublished data), so these age classes represent more than 30 years of seedling establishment. Consequently, the small size of recent cone crops cannot fully explain the scarcity of seedlings and saplings. Our seedling censuses suggest that the rate of Jeffrey pine regeneration, at least in recent decades, in the SSPM is much slower than that at our eastern Sierra Nevada site.

In the not-too-distant past, frequent natural fires in the SSPM would have removed many seedlings and saplings, but fire has been suppressed in the SSPM since the 1970s (Stephens et al. 2003). The absence of fire for $\sim 40$ years should have provided ample opportunity for seedling establishment. In contrast, fire has been suppressed in the eastern Sierra Nevada for about 100 years, so the abundance of seedlings and saplings in those unburned forests probably represents unnaturally high densities, compared to presettlement times. In recent decades, neither site has experienced fire, so we cannot attribute the difference in recruitment solely to the difference in fire regime between the 2 sites. The lack of recent recruitment in the SSPM also does not appear related to recent climate change. Unfortunately, climate data for the SSPM are very limited (climate data collected at the nearby observatory only goes back a few decades and does not include accurate measurement of winter precipitation). Tree-ring and fire-scar studies have not revealed any evidence of strong climate change (Stephens et al. 2003, Evett et al. 2007). Aside from this lack of climate information, climate change usually affects plant distributions by changing recruitment and mortality at the edge of the species' elevation range while having less effect near the middle of the elevation range (e.g., Gworek et al. 2007). Our study site at the SSPM is $\sim 420 \mathrm{~m}$ above the species' lower distributional limit (e.g., above the ecotone between Jeffrey pine forest and the piñon forest at lower elevation), and our study site in the eastern Sierra Nevada is $\sim 400 \mathrm{~m}$ above the species' lower distribution limit. Given the similar position of these sites relative to the lower elevation limit of Jeffrey pine, one would predict a similar effect on seedling abundance if warming climate has reduced seedling recruitment, which does not appear to be the case. So changes in the regional climate do not appear to be the cause of reduced seedling recruitment in the SSPM.

It is possible that grazing by cattle in recent years has suppressed conifer regeneration. This explanation seems unlikely because cattle appear to focus much of their grazing in the area's meadows (vallecitos; Minnich et al. 2000, Evett et al. 2007), which are away from our study plots. The lack of cattle feces in the forest also indicates that grazing in the area is light. Further, Minnich et al. (2000) concluded that cattle do not appear to affect conifer regeneration in the SSPM.

The sparse shrub cover in much of the highelevation forests of the SSPM may have resulted in low seedling establishment. Minnich et al. (2000) estimated shrub and forb cover at $4 \%$ in the SSPM. Shrubs, which are dense (typically $25 \%-90 \%$ cover) in many parts of the Sierra Nevada, often serve as nurse plants for pine regeneration (Briggs et al. 2009, Legras et al. 2010); seedlings that emerge under shrubs experience lower temperatures and greater soil moisture than seedlings growing in the open and exposed to direct sun. In Nevada, 94\% of seedlings that emerge in the open die within 2 years (Legras et al. 2010). Shrub density in much of the SSPM is very low, perhaps a consequence of frequent natural fires, although this part of the forest has not burned in more than 40 years. Stephen and Gill (2005) have suggested that available safe sites for pine regeneration in the SSPM are limited. Although, 
it seems likely that shrub densities in presettlement Sierra Nevadan forests were markedly lower than densities today, and this would likely have reduced seedling recruitment in those forests. However, this explanation does not seem entirely adequate to explain the low level of pine recruitment in the forests of the SSPM. If Jeffrey pine seedlings can only recruit under shrubs, then we would have found some seedlings growing under shrubs, which we did not. Further, if seed germination is high and seedling survival very low, we would have observed some dead and dying seedlings and seedling clumps, which can persist for several years. We did not.

Our observations suggest an alternative explanation, that most seeds, although cached in large numbers, do not survive to the time of seed germination in the SSPM. The reason may be that, although rodents store similar quantities of seeds in the SSPM and Sierra Nevada, rodents in the SSPM may make a greater demand on those stored seed resources. We suspect that this may be the case because the duration of rodent euthermic activity in the SSPM is longer than in the Sierra Nevada. In the northern Sierra Nevada, Jeffrey pine cones at midelevation shed most seeds starting in the second week of September. During the approximately 2 months between seed fall and the onset of winter (mid-November), chipmunks gather and scatter hoard thousands of seeds (e.g., Vander Wall 2002, Briggs et al. 2009). As winter snows begin to accumulate, chipmunks transfer some of these seeds into a larder in their winter burrows and become dormant (Kuhn and Vander Wall 2008). Because they are torpid, these rodents demand far less food than they would have if they had been active all winter long (Kuhn and Vander Wall 2008). Caches that are not retrieved by rodents in fall are inaccessible under the snowpack until spring. When the snow does melt in spring, rodents resume foraging for cached seeds, but those seeds that remain in caches germinate $2-3$ weeks after chipmunks emerge from their winter dens. Thus, in the northern Sierra Nevada, many of the rodents that consume pine seeds are only active for about 3 of the 8 months between seed release from cones and seed germination.

We suspect that the situation is very different in the SSPM. Because of its more southern latitude, its smaller land mass, and its proximity to the Sonoran Desert (only $\sim 10 \mathrm{~km}$ to the east of our study site), the SSPM has milder winters. Although we have not visited the SSPM in winter, we suspect that rodents enter dormancy later, stay dormant for less time, and are periodically active during the winter. Because a euthermic chipmunk requires about 143 times more energy per day than a dormant chipmunk (Place et al. 2002, Kuhn and Vander Wall 2008), a much shorter torpor duration results in a dramatically greater demand on stored food reserves (Humphries et al. 2003). In the case of California chipmunks, which are periodically active during winter in the SSPM, much of this food probably comes from seed caches, most of which are probably depleted by spring. In summary, we hypothesize that the long, intense winter at high latitudes serves to protect cached seeds and thereby facilitate seed dispersal mutualisms. We also hypothesize that the mild winters at lower latitudes fail to do so. Future study should evaluate the relative importance of this and alternative hypotheses.

Our results suggest that small mammals, through their harvesting and scatter hoarding of seeds, are responsible for the dispersal and establishment of Jeffrey pine (and probably sugar pine as well) in the SSPM, but that, from the perspective of the plant, this interaction is weaker than that in the Sierra Nevada, USA. We view the Jeffrey pine-rodent interaction in the SSPM as a mutualism despite the relatively few seedlings produced, because there appears to be a sufficient number of seedlings to cause an increasing population of Jeffrey pine (e.g., Minnich et al. 2000). As has been found elsewhere (Bronstein 1994, Pearson and Theimer 2004, Gworek et al. 2007, Enders and Vander Wall 2012), the strength of species interactions depends on ecological conditions. In fact, the geographic mosaic theory of coevolution (Thompson 1994) predicts that the intensity of species interactions should vary in space and time. In this case, it appears that warmer climate has increased the seasonal activity of granivorous rodents in the SSPM, causing them to be more effective granivores. The balance between granivores having a beneficial effect and being antagonistic appears to have shifted in the direction of antagonism in the SSPM, while being more beneficial in the Sierra Nevada. It is possible that future climate change could intensify these effects: warming climates are likely to increase the euthermic activity of 
chipmunks, thereby increasing their seed consumption and decreasing their effectiveness as dispersers of pine seeds.

\section{ACKNOWLEDGMents}

We thank Scott Stephens and Ernesto Franco for logistical support. Scott Stephens made helpful comments on an early version of the manuscript. We thank Lydia and Abel Bedoya for providing accommodations in Playas de Rosarito, Mexico.

\section{Literature Cited}

Agee, J.K., And C.N. Skinner. 2005. Basic principles of forest fuel reduction treatments. Forest Ecology and Management 211:83-96.

BEATY, R.M., AND A.H. TAYLOR. 2008. Fire history and the structure and dynamics of a mixed conifer forest landscape in the northern Sierra Nevada, Lake Tahoe Basin, California, USA. Forest Ecology and Management 255:707-719.

BRigGS, J.S., S.B. VANDER WALL, and S.H. Jenkins. 2009. Forest rodents provide directed dispersal of Jeffrey pine seeds. Ecology 90:675-687.

Bronstein, J.L. 1994. Conditional outcomes in mutualistic interactions. Trends in Ecology and Evolution 9:214-217.

Brown, R.T., J.K. Agee, and J.F. Franklin. 2004. Forest restoration and fire: principles in the context of place. Conservation Biology 18:903-912.

Collins, B.M., R.G. Everett, and S.L. Stephens. 2011. Impacts of fire exclusion and recent managed fire on forest structure in old growth Sierra Nevada mixedconifer forests. Ecosphere 2:art51, http://dx.doi.org/ 10.1890/ES11-00026.1

ENDERS, M.S., AND S.B. VANDER WaLL. 2012. Black bears (Ursus americanus) are effective seed dispersal agents, with a little help from their friends. Oikos 121:589-596.

Evett, R.R., E. Franco-Vizcaino, and S.L. Stephens. 2007. Phytolith evidence for the absence of a prehistoric grass understory in a Jeffrey pine-mixed conifer forest in the Sierra San Pedro Mártir, Mexico. Canadian Journal of Forest Research 37:306-317.

Finch, D.M., J.L. GaneY, W. Yong, R.T. Kimball, and R. SALLABANKS. 1997. Effects of interactions of fire, logging, and grazing. In: W.M. Block and D.W. Finch, technical editors, Songbird ecology of southwestern ponderosa pine forests: a literature review. General Technical Report RM-GTR-292, Rocky Mountain Forest and Range Experiment Station, USDA Forest Service, Fort Collins, CO. 152 pp.

GWoreK, J.R., S.B. VANDER WALL, AND P.F. BRUSSARd. 2007. Changes in biotic interactions and climate determine recruitment of Jeffrey pine along an elevation gradient. Forest Ecology and Management 239:57-68.

Humphries, M.M., D.L. Kramer, and D.W. Thomas. 2003. The role of energy availability in mammalian hibernation: an experimental test in free-ranging eastern chipmunks. Physiological and Biochemical Zoology $76: 180-186$.
KuHN, K.M., AND S.B. VANDER WALL. 2008. Linking summer foraging to winter survival in yellow-pine chipmunks (Tamias amoenus). Oecologia 157:349-360.

Laughlin, D.C., J.D. Bakker, M.T. Stoddard, M.L. Daniels, J.D. Springer, C.N. Gildar, A.M. Green, and W.W. Covington. 2004. Toward reference conditions: wildfire effects on flora in an old-growth ponderosa pine forest. Forest Ecology and Management 199:137-152.

Legras, E.C., S.B. Vander WaLL, and D.I. Board. 2010. The role of germination microsite in the establishment of sugar pine and Jeffrey pine seedlings. Forest Ecology and Management 260:806-813.

Lindstrom, S. 2000. A contextual overview of human land use and environmental conditions. Pages 23127 in D.D. Murphy and C.M. Knopp, editors, Lake Tahoe Watershed Assessment. Volume 1, General Technical Report PSW-GTR-175, Pacific Southwest Research Station, USDA Forest Service, Albany, CA.

LONGLAND, W.S., AND C. CLEMENTS. 1995. Use of fluorescent pigments in studies of seed caching by rodents. Journal of Mammalogy 76:1260-1266.

Minnich, R.A., M.G. Barbour, J.H. Burk, and J. SosaRAMIEZ. 2000. California mixed-conifer forests under unmanaged fire regimes in the Sierra San Pedro Mártir, Baja California, Mexico. Journal of Biogeography 27:105-129.

North, M., K. Van de Water, S.L. Stephens, and B. CoLlins. 2009. Climate, rain shadow, and human-use influences on Eastern Sierra Nevada fire regimes. Fire Ecology 5:20-34.

Parsons, D.J., and S.H. DeBenedetti. 1979. Impact of fire suppression on a mixed-conifer forest. Forest Ecology and Management 2:21-33.

Pearson, K.M., and T.C. Theimer. 2004. Seed-caching responses to substrate and rock cover by two Peromyscus species: implications for pinyon pine establishment. Oecologia 141:76-83.

Place, N.J., C. Veloso, G.H. Visser, and G.J. Kenagy. 2002. Energy expenditure and testosterone in freeliving male yellow pine chipmunks. Journal of Experimental Zoology 292:460-467.

Stephens, S.L. 2001. Fire history differences in adjacent Jeffrey pine and upper montane forests in the eastern Sierra Nevada. International Journal of Wildland Fire 10:161-167.

2004. Fuel loads, snag abundance, and snag recruitment in an unmanaged Jeffrey pine-mixed conifer forest in northwestern Mexico. Forest Ecology and Management 199:103-113.

Stephens, S.L., And D.L. Fry. 2005. Spatial distribution of regeneration patches in an old-growth Pinus jeffreyi-mixed conifer forest in northwestern Mexico. Journal of Vegetation Science 16:693-702.

StepHENS, S.L., AND S.J. GILL. 2005. Forest structure and mortality in an old-growth Jeffrey pine-mixed conifer forest in north-western Mexico. Forest Ecology and Management 205:15-28.

Stephens, S.L., AND L.W. Ruth. 2005. Federal forest-fire policy in the United States. Ecological Applications 15:532-542.

Stephens, S.L., C.N. Skinner, and S.J. GiLl. 2003. Dendrochronology-based fire history of Jeffrey pinemixed conifer forests in the Sierra San Pedro Martir Mexico. Canadian Journal of Forest Research 33: 1090-1101. 
TAYLOR, A.H. 2004. Identifying forest reference conditions on early cut-over lands, Lake Tahoe Basin, USA. Ecological Applications 14:1903-1920.

TAYLOR, A.H., AND R.M. BEATy. 2005. Climatic influences on fire regimes in the northern Sierra Nevada Mountains, Lake Tahoe Basin, Nevada, USA. Journal of Biogeography 32:425-438.

ThaYer, T.C., AND S.B. VANDER WALL. 2005. Interactions between Steller's jays and yellow pine chipmunks over scatter-hoarded sugar pine seeds. Journal of Animal Ecology 74:365-374.

Thompson, J.N. 1994. The coevolutionary process. University of Chicago Press, Chicago, IL. 383 pp.

ToмвасK, D.F. 1978. Foraging strategies of Clark's nutcrackers. Living Bird 16:123-161.

VAILlant, N.M., AND S.L. STEPHENS. 2009. Fire history of a lower elevation Jeffrey pine-mixed conifer forest. Fire Ecology 5:4-19.

VANDER WalL, S.B. 1994. Removal of wind-dispersed pine seeds by ground-foraging vertebrates. Oikos 69:125-132.

1995. Sequential patterns of scatter hoarding in yellow pine chipmunks. American Midland Naturalist 133:312-321.
2000. The influence of environmental conditions on cache recovery and cache pilferage by yellow pine chipmunks (Tamias amoenus) and deer mice (Peromyscus maniculatus). Behavioral Ecology 11:544-549.

2002. Masting in animal-dispersed pine facilitates seed dispersal. Ecology 83:3508-3516.

2003. Effects of seed size of wind-dispersed pines (Pinus) on secondary seed dispersal and the caching behavior of rodents. Oikos 100:25-34.

2008. On the relative contributions of wind vs. animals to seed dispersal of four Sierra Nevada pines. Ecology 89:1837-1849.

Vander Wall, S.B., T.C. Thayer, J.S. Hodge, M.J. Beck, AND J.K. Roth. 2001. Scatter-hoarding behavior of deer mice (Peromyscus maniculatus). Western North American Naturalist 61:109-113.

Received 23 June 2011 Accepted 6 July 2012 